\title{
Malignant teratoid medulloepithelioma. A case report
}

\section{Meduloepitelioma teratoide maligno. Reporte de caso}

\author{
Welsi J. García-Barbosa* and Alfredo Lizárraga-Corona
}

Department of Ophthalmology, Hospital de Pediatría, Centro Médico Nacional de Occidente, Instituto Mexicano del Seguro Social, Guadalajara, Mexico

\begin{abstract}
Intraocular medulloepithelioma is an uncommon embryonic tumor. Its diagnosis is based on the clinical findings such as-the presence of a ciliary body tumor, intratumoral cysts confirmed by ultrasound, iris neovascularization, corectopia, uveal ectropion and retrolental membrane. Diagnosis is confirmed by the pathology report. We present the case of a malignant teratoid medulloepithelioma confined to the eyeball in a 1-year-old patient. Metastasis evaluation was negative, so she remained under close ophthalmological and oncological surveillance after enucleation. Compared with other intraocular tumors, $m$ medulloepithelioma is more likely to develop secondary glaucoma, a complication that has been described in $60 \%$ of these tumors, probably secondary to iris neovascularization. In pediatric patients who attend consultation due to buphthalmos and congenital glaucoma under evaluation, it is important to exclude intraocular tumors through imaging studies for timely diagnosis and treatment. Retinoblastoma, rhabdomyosarcoma, neuroblastoma, vascular malformations, hematic cysts, glioneuroma and persistent hyperplastic primary vitreous, should be considered in the differential diagnosis. Malignant teratoid medulloepithelioma has a risk of mortality of $10 \%$, related to intra and extracranial dissemination (mainly to regional lymph hodes).

Key words: Intraocular medulloepithelioma. Teratoid medulloepithelioma. Ciliary body tumor. Intraocular tumor. Glaucoma.
\end{abstract}

\section{Resumen}

El meduloepitelioma intraocular es un tumor embrionario poco frecuente. El diagnóstico clínico se establece mediante la presencia de tumor a nivel de cuerpo ciliar, quistes intratumorales confirmados mediante ultrasonido, aunado a características clínicas como neovascularización iridiana, corectopia, ectropión uveal, membrana ciclítica retrolental. La confirmación del diagnóstico se hace mediante estudio histopatológico. El tratamiento estándar es enucleación. Presentamos el caso de un meduloepitelioma teratoide maligno confinado al globo ocular en una paciente de 1 año de edad. Los estudios dé extensión fueron negativos, por lo que se mantuvo en vigilancia estrecha por el Servicio de Oftalmología y Servicio de Ongcología Pediátrica después de la enucleación. Comparado con otros tumores intraoculares, el meduloepitelioma tienezuna fuerte tendencia a producir glaucoma secundario, se ha descrito que el 60\% de estos tumores desarrollarán hipertensión ocular. Esto parece deberse a la neovascularización iridiana. Es importante en pacientes de edad pediátrica que acudên a consulta con un cuadro clínico de buftalmos, además de la sospecha de glaucoma congénito, buscar de manera inteñcionada la presencia de un tumor intraocular mediante estudios de imagen, y así brindar un tratamiento adecuado y oportuno. Clínica e histológicamente, el diagnóstico diferencial se debe realizar con el retinoblastoma, rabdomiosarcoma, neurobjas-

Date of reception: 12-06-2018 C.P. 44660 , Guadalajara, Jal., México E-mail: welsigarcia@gmail.com 2604-1731/O 2020 Sociedad Mexicana de Oftalmología. Published by Permanyer. This is an open access article under the CC BY-NC-ND license (http:// creativecommons.org/licenses/by-nc-nd/4.0/). Date of acceptance: 16-08-2018 DOI: 10.24875/RMOE.M20000094
Available online: 02-01-2020 Rev Mex Oftalmol (Eng). 2020;94(1):41-45 www.rmo.com. $m x$ 
toma, malformaciones vasculares, quistes hemáticos, glioneuroma y con la hiperplasia primaria del vítreo. El meduloepitellioma teratoide maligno tiene un riesgo de mortalidad del 10\%, relacionado con la extensión intra y extracraneal (principalmente a ganglios linfáticos regionales).

Palabras clave: Meduloepitelioma intraocular. Meduloepitelioma teratoide. Tumor del cuerpo ciliar. Tumor intraocular. Glaucoma.

\section{Introduction}

Intraocular medulloepithelioma is a rare embryonic tumor, which mainly affects the ciliary body, previously described as teratoneuroma ${ }^{1}$. It is usually unilateral and focal, although there are bilateral cases. It can affect other organs derived from the neuroepithelium, such as the retina, the optic nerve and the iris $^{2}$. In the central nervous system, it is generally periventricular, with an involvement of the temporal, parietal, occipital and frontal lobes by decreasing frequency ${ }^{1}$. It has been classified as teratoid and non-teratoid. Non-teratoid medulloepithelioma is a cellular proliferation of the neuroepithelium, and teratoid medulloepithelioma is characterized by the presence of additional heterologous elements, particularly cartilage, skeletal muscle and brain tissue. Based on the histopathological criteria, both types can be benign or malignant ${ }^{3}$. The malignancy criteria are: 1) areas of poorly differentiated retinoblastoma-like cells, 2) presence of a sarcomatoid or anaplastic component, 3) invasion of the uvea or sclera, 4) cellular pleomorphism, 5) mitosis and 6) extraocular invasion?2.

The diagnosis of medulloepithelioma is mainly histopathological. In some cases, the presence of mucopolysaccharides is useful for confirmation. Immunohistochemistry is useful to identify heterotopic cellular elements and neuroepithelium, especially in poorly differentiated tumors, in which rosette and/or cord formation is not identified ${ }^{1}$.

In small tumors, local excision via iridocyclectomy, along with radiotherapy, has shown variable success, since these cases frequently recur and require a second intervention with enucleation. Some malignant medulloepitheliomas are treated with brachytherapy in combination with surgical excision; however, once the diagnosis is made, the standard treatment is enucleation. Exenteration is required if the tumor extends beyond the eyeball. If it is a metastatic tumor, combined treatment is initiated with chemotherapy and brachytherapy ${ }^{4}$.

Two thirds of medulloepitheliomas are malignant and have a $10 \%$ mortality rate. The most frequent cause of death is secondary to intra and extracranial extension, the latter is mainly to regional lymph nodes ${ }^{2}$.

\section{Case presentation}

We present the case of a female patient of 1 year and 5 months of age, who is taken to consultation by her mother due to a noticeable increase in the size of her right eyeball in the last 6 months, accompanied by irritability. She was evaluated by the Ophthalmotogy Service at the Hospital Pediátrico (HP) of the Centro Médico Nacional de Occidente (CMNO), where a diagnostic evaluation was initiated.

On physical examination we observed the right eye without response to visual stimulation, buphthalmos, decreased eye movements in all positions of gaze in the right eye, megalocornea and corneal opacity that prevented the evaluation of the anterior segment structures due to the loss of anatomy; right fundus not evaluable; left eye without alterations (Fig. 1).

A- and B-mode ultrasound of the right eye (Fig, 2) revealed an eyeball with a normal shape, with an-anteroposterior diameter of $26.85 \mathrm{~mm}$, crystalline Tens with anterior displacement, small dense areas of $\mathrm{very}$ high reflectivity, compatible with calcifications, dense membranes with a high reflectivity, corresponding to complete retinal detachment with an underlying cysstic zone and $360^{\circ}$ thickened choroid.

T1 magnetic resonance imaging showed an hyperintense image involving approximately $50 \%$ of the intraocular content, with no evidence of bone or adjacent soft tissue involvement.

Enucleation was performed and sent for histopathological study, which revealed an eyeball with an anteroposterior diameter of $27 \mathrm{~mm}$ (Fig. 3) and a 15-mm optic nerve portion; no corneal limit was defined. Under evaluation a tumor was observed that occupied $65 \%$ of the eyeball and retracted the retina, located in the anterior part of the eyeball in close contact with the corneas no conserved architecture of the ciliary body and iris was observed. The tumor had a diameter of $25 \mathrm{~mm}$-with moderately defined borders, a gray-white coloration and a heterogeneous consistency.

The diagnosis was of a malignant teratoid medutoepithelioma with islands of mature hyaline cartitage (Figs. 4 and 5), poorly differentiated foci of neuroblastic differentiation, a sarcomatous component of spindle cells and chondrosarcoma with a high mitotic index The 


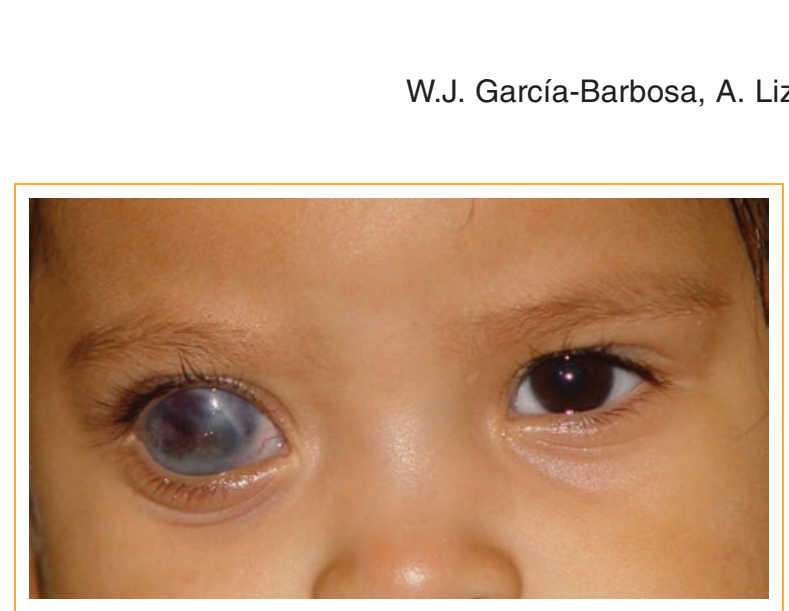

Figure 1. Clinical image at diagnosis in the first consultation.

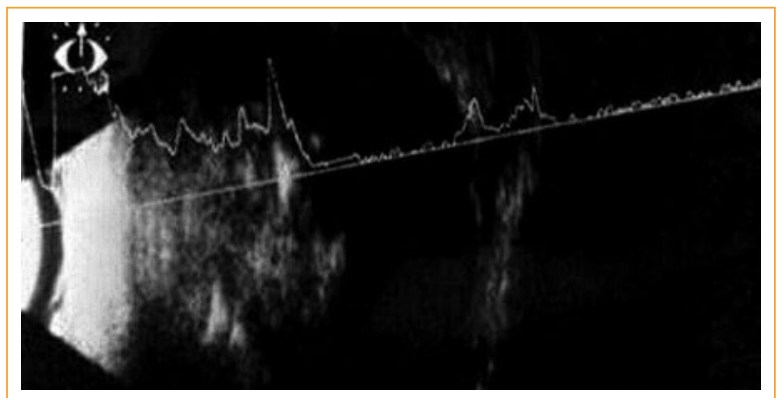

Figure 2. A- and B-mode ultrasound. Eyeball with a normal shape, with an anteroposterior diameter of $26.85 \mathrm{~mm}$, crystalline lens with anterior displacement, small dense high-reflectivity areas compatible with calcifications, highly reflective dense membranes corresponding to a complete retinal detachment with an underlying cystic zone.

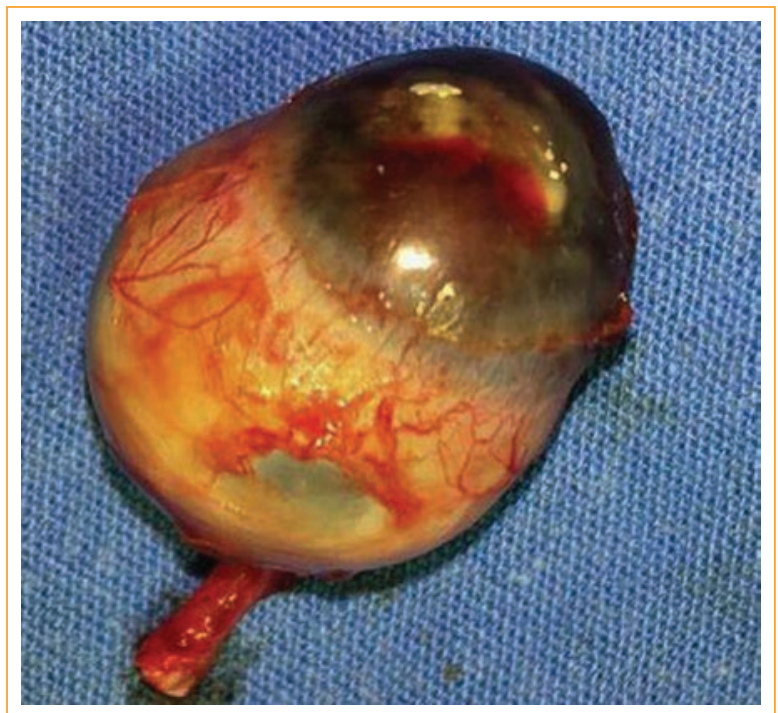

Figure 3. Eyeball and optic nerve portion.
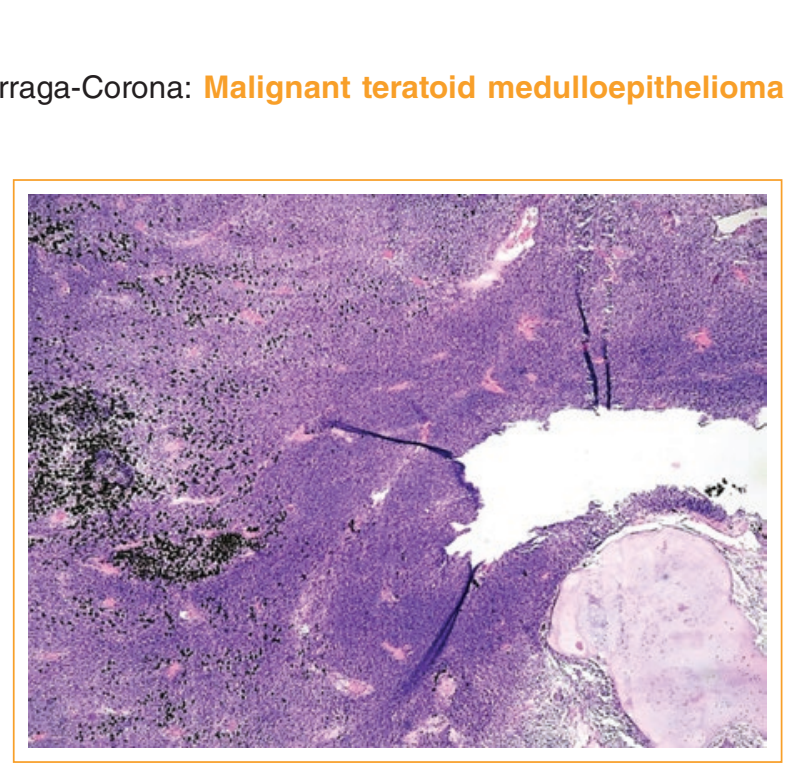

Figure 4. In this field a sarcomatous area is observed, forming a distinctive pattern in fascicles, with dense $\frac{}{v}$ cellularity. At higher magnification, the presence of $-\bumpeq$ numerous mitosis and a fusiform nuclear morphology with few cytoplasm is corroborated. This componentas located adjacent to an island of cartilage (lower right) (HE stain) (original magnification 40x).
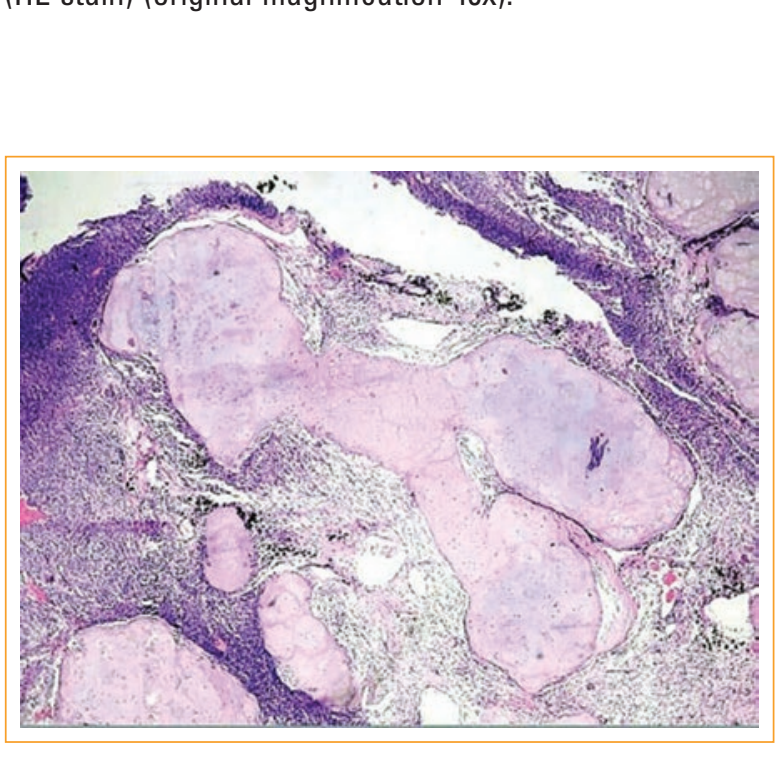

Figure 5. A large island of hyaline cartilage is observed in the central portion, surrounded by the same immature cell population. Similar histological pattern (HE stain)(original magnification 40x).

tumor was infiltrating the cornea (Fig. 6), uveal tissue and anterior sclera in its internal two thirds, as well as the retina. The observed segment of the optic nerve-was tumor-free.

She was assessed by the Medical Oncology Service of the CMNO HP, requesting studies for tumor extension, and no systemic involvement was observed. Currently, the patient is being followed-up at the Ophthalmology Service and the Pediatric Oncology Service 


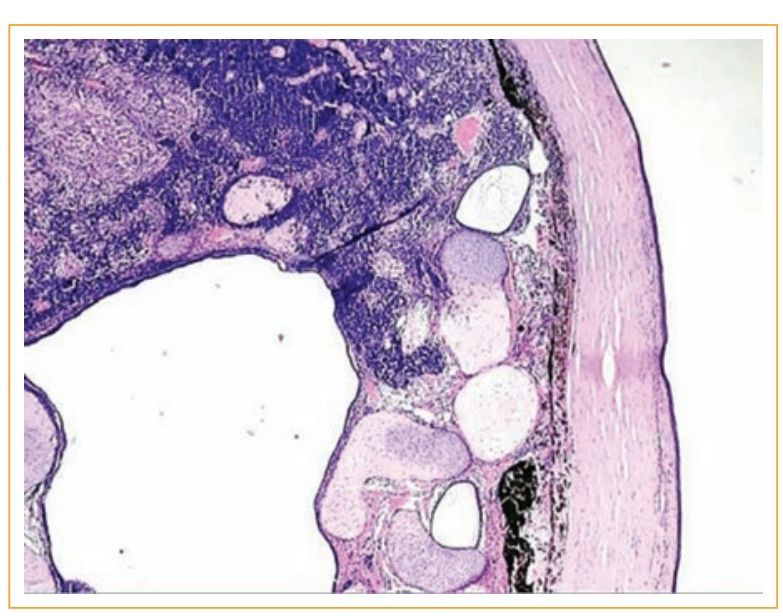

Figure 6. Cystic structures with adjacent mature cartilage islands, surrounded by a dense, intensely basophilic cell population, corresponding to poorly differentiated neuroepithelial cells. On the right, the cornea is observed, with attached uveal tissue (HE stain) (original magnification 40x).

of the CMNO HP, with no recurrence at 18 months of follow-up after diagnosis.

\section{Discussion}

Intraocular medulloepithelioma is a rare neoplasm typically diagnosed in the first decade of life as a ciliary body tumor ${ }^{3}$, with a mean age of presentation at 5 years old $^{5}$. There are few reports of meduloepithelioma in the past decades; in a series of 56 reported cases of non-syndromic medulloepitheliomas, the mean presentation was at 3.8 years, with no sex predominance ${ }^{6}$.

Clinical diagnosis is established by the presence of a tumor at the level of the ciliary body, intratumoral cysts confirmed by ultrasound, along with clinical features such as iris neovascularization, corectopia, uveal ectropion, lens changes (cataract, lens dislocation, coloboma) and retrolental fibrovascular membrane. The diagnosis is confirmed by histopathology 5 .

Visual loss in patients diagnosed with medulloepithelioma is secondary to the presence of a fibrovascular neoplastic membrane, cataract or lens subluxation. Compared to other intraocular tumors, medulloepithelioma has a strong tendency to produce secondary glaucoma, since it has been described that $60 \%$ of these tumors induce ocular hypertension. Glaucoma seems to be secondary to the development of iris neovascularization; therefore, in pediatric patients with neovascular glaucoma and a normal posterior fundus, there should be a high suspicion of an occult medulloepithelioma of the ciliary body ${ }^{3}$. Within the diagnostic evaluation of our patient, by observing a clinical picture of buphthalmos and megalocornea, one of the main differential diagnoses considered was congenital glaucoma; however, since it was not possible to assess the other intraocular structures due to corneal opacity and anatomic alterations of the anterior segment, it was of vital importance carrying out complementary studies to document the state of the anterior and $\overline{\text { pos- }}$ terior segments of the eye, due to the probability of an intraocular tumor. Clinically and histologically, the-differential diagnosis include retinoblastoma, rhabdomyosarcoma, neuroblastoma, vascular malformations, blood cysts, glioneuroma and persistent hyperplastic primary vitreous ${ }^{7,8}$. Clinical findings that may help distinguish a medulloepithelioma from a retinoblastoma include glaucoma $(44 \%)$, iris neovascularization $(5 \underline{1} \%)$, cataract $(20 \%)$, lens dislocation $(27 \%)$, lens coloböma $(20 \%)$, and retrolental fibrovascular membrane, as zwell as the presence of intratumoral cysts $(61 \%$ in both cases) $)^{6}$.

A clinical feature suggestive of medulloepithelioma is the presence of intratumoral cysts surrounded by neuroepithelium and with a matrix rich in hyaluronic acid, analogous to the vitreous content ${ }^{3}$; therefore, if the $u l-$ trasound shows a highly reflective tumor with structural irregularity associated with cystic changes that involve the ciliary body, a presumptive diagnosis of medulloepithelioma should be established ${ }^{9}$.

Several studies report that, despite being a malignant tumor, it does not tend to induce distant metastasis unless it is an extraocular extension of a primary lesion ${ }^{3}$. The possibility of such affectation is evaluated with imaging studies. In the case of our patient, sthe orbit and skull magnetic resonance study showed no involvement of the central nervous system, so currently the patient is being followed-up at the Pediatric Oncology Service.

\section{Conclusions}

Intraocular medulloepithelioma is a rare tumor, diagnosed mainly in the first decade of life. It presents with different clinical signs of the anterior segment, one of the most common being iris neovascularization that represents one of the main causes for glaucoma development in patients with a delayed diagnosis.

It is important that, in patients of pediatric age with a clinical picture of buphthalmos and megalocornea, in 
addition to the suspicion of congenital glaucoma, other pathologies associated with the described clinical picture should be evaluated, intentionally seeking an intraocular tumor by imaging studies in order to provide an adequate and timely treatment.

Histopathological study is of vital importance for therapeutic decisions and prognostic evaluation. Malignant teratoid medulloepithelioma has a $10 \%$ mortality rate that is dependent on extraocular involvement. In the case of our patient, since the tumor was confined to the eyeball with a low tendency to metastasize, only close surveillance is recommended to detect a possible recurrence of the tumor or an intra- and/or extracranial involvement, since those are the leading causes of death in this type of tumor.

\section{Ethical disclosures}

Protection of human and animal subjects. The authors declare that no experiments were performed on humans or animals for this study.

Confidentiality of data. The authors declare that they have followed the protocols of their work center on the publication of patient data.

Right to privacy and informed consent. The authors have obtained the written informed consent of the patients or subjects mentioned in the article. The corresponding author is in possession of this document.

\section{Funding}

The authors received no specific funding for this work.

\section{Conflicts of interest}

The authors declare no conflicts of interest.

\section{References}

1. Inzulza Barrientos N, Matus Matus G, Torres Marín R. Meduloepiteilioma en el adulto. Rev Mex Oftalmol [Internet]. 2014;88(3):128-36. Disponbible en: http://www.sciencedirect.com/science/article/pii/S0187451914000481

2. Danny Soria-Céspedes, Fernando Martínez-Madrigal, Pedro Méndez-Sashida $\mathrm{CO}-\mathrm{H}$. Meduloepitelioma pigmentado maligno intraøeular. Presentación de dos casos Intraocular malignant pigmented medulttoepithelioma. A report of two cases. Rev Esp Patol. 2009;42(3):225-9.

3. Shields JA, Eagle RC, Shields CL, De Potter P. Congenital Neoptasms of the Nonpigmented Ciliary Epithelium (medulloepithelioma). Ophthalmology [Internet]. 1996;103(12):1998-2006. Disponible en: http:/Hinkinghub.elsevier.com/retrieve/pii/S0161642096303941

4. Rao AA, Naheedy JH, Chen JYY, Robbins SL, Ramkumar HL. A clinical update and radiologic review of pediatric orbital and ocular tumers. $J$ Oncol. 2013;2013:1-22.

5. Kaliki S, Shields CL, Eagle RC, Vemuganti GK, Almeida A, Manjañavida FP, et al. Ciliary body medulloepithelioma: Analysis of 41 táses. Ophthalmology [Internet]. 2013;120(12):2552-9. Disponible en: http $/ / d x$. doi.org/10.1016/j.ophtha.2013.05.015

6. Jakobiec FA, Trief D, Rashid A, Rose MF, Minckler D, Vanderveen D, et al. New insights into the development of infantile intraocular. meduIloepithelioma. Am J Ophthalmol [Internet]. 2014;158(6):1275-96.e है Disponible en: http://dx.doi.org/10.1016/j.ajo.2014.08.036

7. Keefe MO, Fulcher T, Kelly P, Lee W, Dudgeon J. Medulloepithelioma of the Optic Nerve Head. Arch Ophthalmol. 2015;115:1325-7.

8. Shields JA, Shields CL, Schwartz RL. Malignant teratoid medulloèpithelioma of the ciliary body simulating persistent hyperplastic primary vitreous. Am J Ophthalmol [Internet]. 1989;107(3):296-8. Disponibte en: http://dx.doi.org/10.1016/0002-9394(89)90318-8

9. Foster RE, Murray TG, Byrne SF, Hughes JR, Gendron BK, Ehlies FJ, et al. Echographic features of medulloepithelioma. Am J Ophthaimol. 2000;130(3):364-6. 